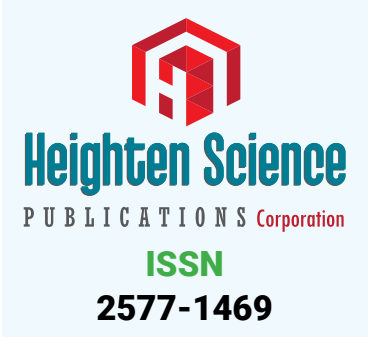

*Address for Correspondence: $Y$ Goncharova, Maternity Hospital, LELEKA, Kyiv, Ukraine, M. Kryvonosa St. 19a, Kyiv, Ukraine 03037; Tel: +380503804239; Email:y.goncharova@ivf.com.ua

Submitted: 04 February 2019

Approved: 11 February 2019

Published: 12 February 2019

Copyright: @ 2019 Sudoma I, et al. This is an open access article distributed under the Creative Commons Attribution License, which permits unrestricted use, distribution, and reproduction in any medium, provided the original work is properly cited

Check for updates
Research Article

\section{Application of autologous adipose- derived stem cells for thin endometrium treatment in patients with failed ART programs}

\author{
I Sudoma ${ }^{1,2}$, L Pylyp ${ }^{1}$, Y Kremenska ${ }^{1}$ and Y Goncharova ${ }^{1,3 *}$ \\ ${ }^{1}$ Clinic of Reproductive Medicine NADIYA, Kyiv, Ukraine \\ ${ }^{2}$ National Medical Academy for Postgraduate Education, PL Shupik, Kyiv, Ukraine \\ ${ }^{3}$ Maternity Hospital LELEKA, Kyiv, Ukraine
}

\section{Introduction}

One of the factors of assisted reproduction technology (ART) success is an adequate growth and development of endometrium. At the end of follicular phase of menstrual cycle endometrium reaches its greatest thickness. It is believed that there is a critical limit of endometrial thickness beyond which the implantation of embryo is unlikely or impossible [1-5]. In practice of ART programs ultrasound measurement of endometrial thickness is used to evaluate uterine lining growth. Scientific literature is debatable as to what thickness of endometrium should be considered optimal, some researchers emphasize the negative impact of "thin endometrium" on the success of ART programs [1-12], while others do not agree [6,7,9]. Nevertheless, when endometrial thickness in ART program does not exceed $6 \mathrm{~mm}$ the chance of pregnancy occurring is very low (Kumbak B, et al. 2009). Endometrium is a unique tissue that has thousands of cycles of growth, differentiation and detachment during woman's life [13-15]. Various organs and tissues are believed to contain stem cells populations that ensure the recovery of these tissues. Cells with multipotent properties were also found in endometrium $[16,17]$. A group of scientists from Australia detected and identified population of mesenchymal stem cells (MSCs) and epithelial progenitor cells in human endometrium $[13,18-20]$. It may be assumed that the absence, lack and defects of MSCs or the absence of signals needed to push their proliferation and differentiation lead to the fact that endometrium is not renewed, thin and unable to provide the implantation of embryo. Endometrial MSCs are adult stem cells similar to those found in other tissues. Therefore, in case of their lack or absence it is logical to assume that endometrial niche can be colonized by autologous stem cells derived from other tissues. In some areas of medicine, autologous stem cells are already used in clinical practice for the repair of damaged tissues and organs, although these methods are still experimental $[21,22]$. There were several publications about the use of stem cells for improving the endometrium growth and structure in experimental (animal) models (Zhao Jing, et al. 2014) and in clinical practice in patients with Asherman syndrome and endometrial athrophy refractory to other types of therapy [23,24], (Singh N, et al. 2014. Santamariya $\mathrm{X}$, et al. 2016). The main source of autologous stem cells is bone marrow. However, lately adipose tissue becomes popular because the procedure of its extraction - liposuction is less traumatic and better tolerated by patients compared to spongy bone puncture for bone marrow obtaining [25]. First MSCs were derived from adipose tissue during its cosmetic extraction in 2001 [26]. These adipose-derived mesenchymal stem cells (ASCs) have rather high capacity for differentiation (multipotency) and proliferation. 
The aim of this work was to study the possibility of autologous ASCs use for the treatment of "thin endometrium" in patients with unsuccessful ART programs.

The protocol of treatment was approved by local ethical committee and patient's informed consent was obtained for it.

\section{Material and Methods}

\section{Patients' selection}

Study group included 25 patients with a thin endometrium (up to $5 \mathrm{~mm}$ ) who were referred for infertility treatment by ART. All of them had multiple (at least 3) in vitro fertilization (IVF) failures. In all of them other different treatment options (high doses of estrogens, granulocyte colony-stimulating factor, hysteroscopy, endometrium scratching, aspirin etc.) failed to improve the thickness of uterine lining. Patients' characteristics are presented in table 1 .

Diagnostic hysteroscopy with histological examination of endometrium was performed in all patients before the treatment with autologous ASCs. In all the patients included in this program embryos were previously collected and frozen (patient's or donor's oocytes were used) (Table1).

Autologous ASCs (about $1 \times 10^{6}$ in $1 \mathrm{ml}$ of culture medium) were injected subendometrially (in several points) under sonographic control by intracavital or transmiometrial injection by means of the needles for amniocentesis (Cook, G16289, 20G/15cm) or oocyte aspiration (Cook, K-OPAA1730, 17G/30 cm). For the first 9 patients we used the needle for amniocentesis, it was introduced through the guide catheter to the uterine cavity. For other patients we use the needle for oocyte aspiration, which was conducted through the myometrium to the area adjacent to endometrium border. This last mode turned out to be more convenient. ASCs introduction was conducted three times with the intervals of 5-7 days while patients were treated with estrogens (Proginova (Bayer HealthCare Pharmaceuticals), 2 to $6 \mathrm{mg}$ for 15 days) in an artificial cycle

Table 1: Clinical characteristics of the patients: the age, the number of implantation failures in previous IVF programs, the use of donor oocytes in previous IVF programs, the thickness of endometrium, the hypothetical cause of thin endometrium.

\begin{tabular}{|c|c|c|c|c|c|}
\hline Patient & Age & IVF failures & Donor oocytes & Endometrium (mm) & Cause \\
\hline №1 & 34 & 16 & No & 4 & Unknown \\
\hline №2 & 37 & 8 & Yes & 5 & Hysteroscopic resection \\
\hline №3 & 41 & 6 & Yes & 4 & Hysteroscopic resection \\
\hline №4 & 45 & 3 & No & 3 & Hysteroscopic resection \\
\hline №5 & 34 & 5 & No & 4 & Unknown \\
\hline №6 & 37 & 6 & Yes & 4 & Unknown \\
\hline №7 & 38 & 7 & No & 4 & Hysteroscopic resection \\
\hline №8 & 40 & 1 & Yes & 2 & Embolisation of uterine arteries (myoma) \\
\hline №9 & 37 & 2 & No & 2 & Hysteroscopic resection, Depo-provera \\
\hline №10 & 39 & 4 & No & 3 & Unknown \\
\hline №11 & 40 & 5 & No & 3 & Hysteroscopic resection \\
\hline №12 & 40 & 8 & No & 4 & Hysteroscopic resection \\
\hline №13 & 34 & 3 & No & 4 & Hysteroscopic resection \\
\hline №14 & 43 & 4 & Yes & 3 & Unknown \\
\hline №15 & 37 & 5 & No & 3 & Unknown \\
\hline №16 & 33 & 7 & No & 4 & Hysteroscopic resection, Depo-provera \\
\hline №17 & 34 & 4 & No & 5 & Embolisation of uterine arteries (myoma) \\
\hline №18 & 39 & 3 & No & 4 & Hysteroscopic resection \\
\hline №19 & 38 & 3 & No & 3 & Depo-provera \\
\hline №20 & 35 & 3 & No & 4 & Hysteroscopic resection \\
\hline №21 & 36 & 5 & No & 5 & Hysteroscopic resection \\
\hline №22 & 37 & 6 & No & 4 & Hysteroscopic resection \\
\hline №23 & 37 & 4 & No & 3 & Hysteroscopic resection \\
\hline №24 & 36 & 8 & No & 3 & Unknown \\
\hline №25 & 35 & 4 & No & 3 & Hysteroscopic resection \\
\hline
\end{tabular}


with gonadotropin-releasing hormone agonist (a-GnRH) pituitary inhibition (Diphereline, $3.75 \mathrm{mg}$ (Beaufour Ipsen)) in women of reproductive age and without a-GnRH in menopausal patients.

In women with preserved ovarian function sonographic endometrial thickness was measured in 3-10 natural menstrual cycles following the treatment, in menopausal patients and patients with impaired ovarian function (anovulation, follicle growth deviation) - in 3-10 artificial cycles with the use of estrogens and, if necessary, a-GnRH. In all artificial cycles (in the cycle of treatment with the introduction of stem cells and the subsequent cycles of observation) progestins were used to simulate luteal phase. If endometrial thickness reached at least $7 \mathrm{~mm}$, the transfer of frozen/thawed embryos was performed.

\section{Isolation and characteristic of ASCs}

Adipose tissue was derived by aspiration from the patient's anterior abdominal wall. Stromal vascular cell fraction was isolated by treatment of adipose tissue with 0,075\% collagenase I (LifeTechnologies), erythrocytes were lysed by lysis buffer (Stem cell Technologies). Cells were cultured in MesenPro RSTM medium (LifeTechnologies). Stem cells were selected by their ability to adhere to the plastic in culture and by the formation of fibroblast-like colonies [27,28]. Replacement of the medium was performed every 4 days and cells passages - at $80 \%$ of cell confluence (Supplementary Figure 1). For the long term storage cells were cryopreserved after 2-3 passages in Recovery Cell Culture Freezing Medium (LifeTechnologies) at a concentration of $1 \times 10^{6}-1 \times 10^{8}$ cells per ml. Differentiation towards adipogenic, chondrogenic and osteogenic lineages was performed to confirm the plasticity of ASCs. Cells were cultured in induction medium (StemPro Chondrogenesis, Osteogenesis, Adypogenesis Differentiation kits, LifeTechnologies) for 21 - 25 days and stained by Oil Red O, Alizarin Red S and Alcian Blue (Supplementary Figure 2). Expression of the primary positive (vascular endothelial marker CD34) and negative (lymphohematopoietic glycoprotein CD45) markers was detected by immunocytochemistry of cultured cells on passage 3 [28]. After fixation in 3.4\% paraformaldehyde cells were incubated in 1\% BSA in PBST for 30 minutes. Primary antibodies (Mouse monoclonal [BI-3C5] to CD34 and Rabbit polyclonal to CD45, Abcam) were applied to the samples for 1 hour, washed with PBS and incubated with secondary antibodies (Goat polyclonal to Mouse IgG (Cy5) and Goat polyclonal to Rabbit IgG (FITC), Abcam) for 1 hour in a dark chamber; washed with PBS, dried and covered with DAPI II (Vysis). Analysis was documented using microscope AxioImager M1 (Zeiss) with Isis software (MetaSystems). To exclude the chromosomal abnormalities, which could indicate the malignant transformation of the cells, cytogenetic analysis was performed both on ASCs primary culture and on cells after freezing-thawing (Supplementary Figure 3). Patient's ASCs were thawed for $2 \mathrm{~min}$ at $37^{\circ} \mathrm{C}$ in a water bath and washed with MesenPro RSTM medium (LifeTechnologies) before introduction.

\section{Hysteroscopy and morphological analysis}

The $5.0 \mathrm{~mm}$ diagnostic hysteroscope (Karl Storz) was used for hysteroscopy. The procedure was performed on 8th $-12^{\text {th }}$ day of natural menstrual cycle or in artificial menstrual cycle in patients receiving estrogens. Histological examination was performed on paraffin-embedded tissue sections stained with Hematoxylin \& Eosin and Van Gieson's Picro-Fucksin dyes. Results were analyzed using Olympus CX-31 microscope.

\section{Results}

The results of hysteroscopy and morphological examination of endometrium are presented in table 2 . In the majority of patients, severe endometrial atrophy with typical features of this condition was observed: no division into basal and functional layers; reduction of endometrial glands number and size (to $10-20 \mathrm{mkm}$ ), glands 
arrangement parallel to the uterine wall; flat, occasionally cuboid glands epithelium, stroma with a high content of collagen fibres (Figure 1 A-D). In some women the features of endometrial hypotrophy were identified, division into functional and basal layers was maintained, the number and size of the glands were reduced, but the epithelium of some glands had the signs of functional one with figures of mitosis and pseudostratification (Figure 1E-H).

The results of sonographic measurement of endometrial thickness in the cycles of observation after ASCs treatment are presented in table 3. The data shows that in 20 of 25 patients ASCs subendometrial injection led to an increase of endometrial thickness. The enlargement of endometrial thickness was seen in the following $1^{1^{\text {st }}-6^{\text {th }}}$ menstrual cycles and in all cases except one do not exceed 6 months. In 5 patients no improvement of endometrial growth was observed. In 2 of them the endometrium was damaged more seriously, the athrophic changes and scar formations were more prominent if to compare to other women. In both cases the histological investigation revealed the lack of glandular and/or stromal component in endometrial tissue (Figure $1 \mathrm{~A}, \mathrm{~B}$ ). Other 3 women who previously received medroxyprogesterone (Depoprovera, Pfizer) treatment for hyperplastic and malignant endometrial lesions also did not answer ASCs treatment.

In 19 women embryo transfers were performed - in 18 women endometrial thickness was at least $7 \mathrm{~mm}$, in one case $-6,5 \mathrm{~mm}$. In total 13 pregnancies were achieved, 11 - after embryo transfers and 2 - after natural conceptions. As a result, 9 healthy babies were born at 35-40 weeks of gestation, 3 miscarriages ( 2 - after ART and 1 - after natural conception) took place and 1 preterm baby was delivered by urgent cesarean section at 30 weeks of gestation with severe health problems due to immaturity and hypoxia. Data on the frozen-thawed embryos programs and pregnancy results are presented in table 4 (patients №4-6, 9,12 had no embryo transfer).

We had the opportunity to check the endometrial thickness of one patient 6 and 8 years after ASCs transplantation. This patient came for transfer of her preserved embryos. It was remarkable that her endometrial thickness was more than $7 \mathrm{~mm}$. And after embryo transfer of 2 thawed embryos in her natural cycle she became pregnant

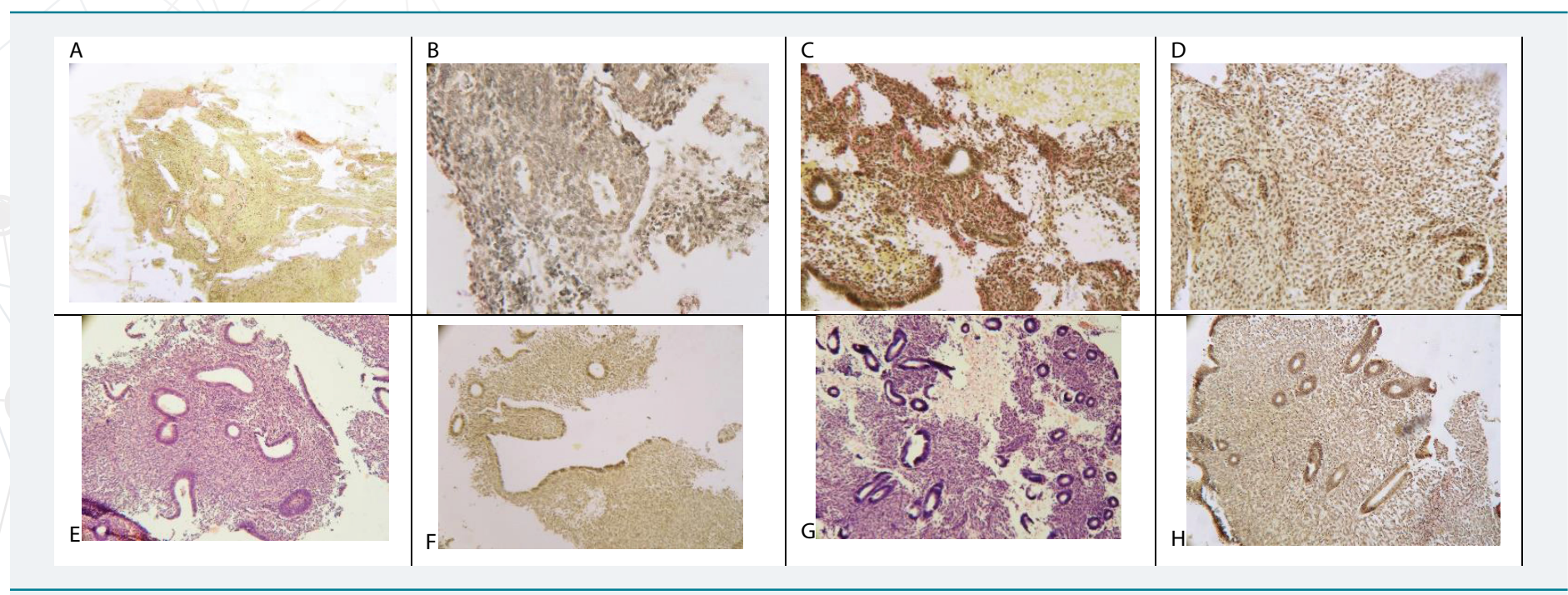

Figure 1: A. Endometrial atrophy, glands without stroma support. Van Gieson's Picro-Fuchsin staining (x100)

B. Endometrial atrophy, single glands with cuboid epithelium. Van Gieson's Picro-Fuchsin staining (x200)

C. Endometrial atrophy. Stroma prevalence, the focuses of fibrosis. Van Gieson's Picro-Fuchsin staining (x200)

D. Endometrial atrophy, single glands with cuboid epithelium. Van Gieson's Picro-Fuchsin staining (x200)

E. Endometrial hypotrophy. Uneven development of endometrial glands, decrease of their portion in stroma. Hematoxylin \& Eosin staining ( $x 100)$

F. Endometrial hypotrophy. Uneven development of endometrial glands, decrease of their portion in stroma. Van Gieson's Picro-Fuchsin staining (x100)

G. Endometrial hypotrophy. Glands generally correspond to follicular phase of menstrual cycle; cylindrical epithelium, mitoses, pseudostratification, stroma with uneven edema, hemorrhage. Hematoxylin \& Eosin staining (x200).

H. Endometrial hypotrophy. Glands with mitoses, pseudostratification. Van Gieson's Picro-Fuchsin staining (x200) 
Table 2: Hysteroscopic and histological features of uterine cavity and endometrium.

\begin{tabular}{|c|c|c|c|c|c|c|c|c|}
\hline \multicolumn{5}{|c|}{ Hysteroscopy } & \multicolumn{4}{|c|}{ Morphological examination } \\
\hline $\begin{array}{l}\text { Number } \\
\text { of cases }\end{array}$ & $\begin{array}{c}\text { Area of } \\
\text { preserved } \\
\text { endometrium } \\
\text { less than } \\
30 \%\end{array}$ & $\begin{array}{c}\text { Thin } \\
\text { endometrium }\end{array}$ & Sinechia & Adenomyosis & Atrophy & Hypoplasia & $\begin{array}{l}\text { Stromal } \\
\text { fibrosis }\end{array}$ & $\begin{array}{c}\text { Absence of } \\
\text { glandular } \\
\text { or stromal } \\
\text { component of } \\
\text { endometrium }\end{array}$ \\
\hline & 2 & 25 & 6 & 3 & 22 & 3 & 10 & 6 \\
\hline
\end{tabular}

Table 3: The results of sonographic measurement $(\mathrm{mm})$ of endometrial thickness in the cycles of follow-up after ASCs treatment.

\begin{tabular}{|c|c|c|c|c|c|c|}
\hline № & 1 cycle & 2 cycle & 3 cycle & 4 cycle & 5 cycle & 6 cycle \\
\hline №1 & 5 & 5 & $6,5^{\star \star}$ & $-\star$ & - & - \\
\hline №2 & 6 & 7 & $7 \star \star$ & - & - & - \\
\hline №3 & 6 & 8 & $8 * *$ & - & - & - \\
\hline №4 & 3 & 5 & 4 & 3 & - & - \\
\hline №5 & 2 & 4 & 2 & 3 & 2 & - \\
\hline №6 & 1 & 3 & 3 & - & - & - \\
\hline №7 & 5 & 5 & 5 & 7 & 7 & $7 * \star$ \\
\hline №8 & 5 & 7 & $7 * \star$ & - & - & - \\
\hline №9 & 4 & 4 & 4 & - & - & - \\
\hline №10 & 6 & $7 \star \star$ & - & - & - & - \\
\hline №11 & 6 & 6,8 & $7,2^{\star \star}$ & - & - & - \\
\hline №12 & 4 & 4 & 4 & 4 & 3,5 & 4 \\
\hline №13 & 6 & 7 & $7 * \star$ & - & - & - \\
\hline №14 & 6 & 6 & 7 & $7 * \star$ & - & - \\
\hline №15 & 5 & 5 & 6,8 & $7,1^{\star \star}$ & - & - \\
\hline №16 & 4 & 5 & 6,1 & $7,1^{\star \star}$ & - & - \\
\hline №17 & 3 & 6,8 & $7 * \star$ & - & - & - \\
\hline №18 & 4 & $7,1^{\star \star}$ & - & - & - & 3 \\
\hline №19 & 5 & 6,1 & 6,6 & $7,2^{\star \star}$ & - & - \\
\hline №20 & 6 & $7,1^{\star \star}$ & - & - & - & - \\
\hline №21 & 5 & $7,4^{\star \star}$ & - & - & - & - \\
\hline №22 & 5 & 6 & $7 \star \star$ & - & - & - \\
\hline №23 & 5 & 6 & 6,8 & $7,1^{*}$ & - & - \\
\hline №24 & 7,2 & - & - & $7,1^{\star \star}$ & - & - \\
\hline №25 & $7,1^{\star \star}$ & - & - & - & - & - \\
\hline \multicolumn{7}{|c|}{$\begin{array}{l}\text { *Natural conception:; }{ }^{\star \star} \text { Cycle of embryo transfer } \\
\text { - Measurement of endometrium was not performed (the reasons for that were pregnancy occurring, other kind of } \\
\text { ART program (surrogacy) or patient's personal reasons). }\end{array}$} \\
\hline
\end{tabular}

\begin{tabular}{|c|c|c|c|c|c|c|c|}
\hline $\begin{array}{l}\text { Patient's } \\
\text { number }\end{array}$ & $\begin{array}{l}\text { Patient's oocytes } \\
\text { (P)/donor's } \\
\text { oocytes (D) }\end{array}$ & $\begin{array}{l}\text { Number of } \\
\text { embryos } \\
\text { transferred }\end{array}$ & \begin{tabular}{|c|}
$\begin{array}{c}\text { Day of } \\
\text { embryo } \\
\text { cultivation }\end{array}$ \\
\end{tabular} & $\begin{array}{l}\text { Embryo } \\
\text { stage }\end{array}$ & $\begin{array}{l}\text { Embryo quality: } \\
\text { excellent (A), good } \\
\text { (B), satisfactory (C) }\end{array}$ & Pregnancy & Outcome \\
\hline №1* & $P$ & 3 & 5 & Blastocysts & $\mathrm{B}, \mathrm{B}, \mathrm{B}$ & No & \\
\hline №2 & D & 2 & 4 & Morula & $A, A^{\star *}$ & Yes & Live birth \\
\hline №3 & D & 2 & 5 & Blastocysts & $A, A$ & Yes & Miscarriage at 24 weeks \\
\hline №7 & $P$ & 1 & 5 & Blastocyst & A & No & \\
\hline №8 & $P$ & 2 & 5 & Blastocysts & $\mathrm{C}, \mathrm{C}$ & No & \\
\hline №10 & D & 2 & 5 & Blastocysts & $\mathrm{C}, \mathrm{C}$ & No & \\
\hline №11 & $P$ & 2 & 5 & Blastocysts & $B, B$ & No & \\
\hline №13 & $P$ & 2 & 5 & Blastocysts & $\mathrm{C}, \mathrm{C}$ & No & \\
\hline №14 & 2 & 2 & 5 & Blastocysts & $A, A$ & Yes & Live birth \\
\hline №15 & $\mathrm{P}$ & 2 & 5 & Blastocysts & $A, A$ & Yes & Live birth \\
\hline №16 & $\mathrm{P}$ & 2 & 5 & Blastocysts & $\mathrm{A}, \mathrm{A}$ & No & \\
\hline №17 & 7 & 2 & 5 & Blastocysts & $A, A$ & Yes & Live birth \\
\hline №18 & 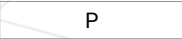 & 2 & 5 & Blastocysts & $A, A$ & Yes & Live birth \\
\hline №19 & $P$ & 2 & 5 & Blastocysts & $A, B$ & No & \\
\hline №20 & $P$ & 2 & 5 & Blastocysts & $A, B$ & Yes & Live birth \\
\hline №21 & $P$ & 1 & 5 & Blastocyst & A & Yes & Live birth \\
\hline №22 & $P$ & 2 & 5 & Blastocysts & $A, B$ & Yes & Live birth \\
\hline №24 & 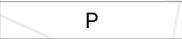 & 1 & 5 & Blastocyst & A & Yes & Live birth \\
\hline №25 & $\mathrm{P}$ & 1 & 5 & Blastocyst & A & Yes & Miscarriage at 8 week \\
\hline
\end{tabular}


with twins and delivered 2 healthy babies on the $35^{\text {th }}$ week of gestation. And again in 2 years (8 years after ASCs transplantation) her endometrium was thick enough - 7,8 $\mathrm{mm}$. The embryo transfer of 2 thawed embryos was fulfilled, and pregnancy occurred. The pregnancy of 12 weeks is ongoing now.

\section{Discussion}

Today human adipose tissue is a promising source for multipotent adult stem cells derivation for regenerative medicine. Autologous ASCs are considered suitable for application in regenerative therapies due to the ability to differentiate into different cell types of tri-germ lineages, trophic factors secretion, low immunogenicity, immunosuppressive properties. Still, the exact mechanisms of ASCs regenerative potential are not well studied and are thought to include direct trans differentiation into cells of the tissue of interest as well as indirect action by the production of paracrine factors, cell survival improvement, activation of cells in the tissue of interest, niche improvement, angiogenesis enhancement, regulation of apoptosis and immunomodulation [29-31].

The reason why we chose adipose tissue as a source of autologous MSCs was mainly due to its advantage over other possible sources of adult stem cells (e.g. bone marrow) - the possibility to easily and repeatedly collect the tissue by minimally invasive techniques with low risk of morbidity and other possible complications.

Our data shows that in 20 of 25 patients (80\%) ASCs subendometrial introduction led to endometrial thickness increase, 13 pregnancies occurred and 9 healthy babies were born. Pregnancy rate for embryo transfer was $57,7 \%$, cumulative live birth rate for woman was $36 \%$. As we know from available sources, these are the first cases of pregnancies and childbirths after autologous ASCs use for endometrium recovery. We already described the first 10 patients cases in 2010, 2012 and 2013 [24,32,33]. In 2011, another group of researchers achieved pregnancy after the use of bone marrow stem cells in woman with Asherman syndrome and thin endometrium [23]. And another study was published in 2016 by investigators from Spain (Santamariya, et al. 2016). In their work they used CD133+ bone marrow derived stem cells which were delivered into the spiral arterioles by catheterization for refractory Asherman syndrome and endometrial athrophy in 16 patients and achieved 7 pregnancies and 2 live births. In all published data different types and quantity of stem cells, as well as the routs of administration, were used for endometrium treatment. Nevertheless, it seems that stem cell therapy could be helpful in recovering of impaired endometrium.

By the moment there is no possibility to draw any convincing conclusion about the relation of patients' age, cause of endometrium thickness reduction and type and location of ASCs introduction with the failure of the treatment on endometrium growth and/or embryo implantation because of limited number of cases.

In our series of cases 5 patients did not respond to the treatment. Two of them had more prominent endometrial damage than other women. We suggest, that this significant mucosal damage (the lack or very small quantity of endometrial tissue elements, scar changes) may make these patients inappropriate candidates for autologous ASCs treatment. Concerning the ineffectiveness of ASCs in patients after medroxyprogesterone treatment we suppose this to be related to endometrial receptor system damage. Both of these hypothesis need to be supported by further research.

Mechanism of ASCs action on tissues and organs is not precisely known. It is believed that every organ has so-called stem cell niche, from where these cells "come", proliferate and differentiate, thus providing tissue restoring [15]. It was proved that MSCs are able to migrate to the area of injury, "to come" into the damaged organ and to turn into "required" local cells $[29,30]$. This suggests that, when administered topically or systemically, they can populate niche and replace damaged local pool of stem cells. 
In addition, they are able to promote tissue regeneration in other ways, strengthening and stimulating vasoformation, inhibiting apoptosis and promoting cell proliferation. It is also believed that these cells have immunomodulatory properties [31].

Thus, the following conclusions may be drawn: 1. The local (subendometrial) introduction of autologous stem cells derived from adipose tissue in patients with thin endometrium in ART programs may lead to an increase of uterine lining thickness. The rate of treatment effect onset and its duration vary significantly among different patients. 2. In women with thin endometrium it is possible to achieve the pregnancy after the treatment with autologous ASCs. 3. Further studies are needed to determine the criteria (hysteroscopic, morphological, etc.) of patients selection for the treatment by autologous stem cells derived from adipose tissue and to identify the possible risks of its application.

\section{References}

1. Check JH, Nowroozi $\mathrm{K}$, Choe L, Dietterich $\mathrm{C}$. The effect of endometrial thickness and echogenic patterns on pregnancy rates during in vitro fertilization. Fertil Steril. 1991; 56: 1173-1175. Ref.: https://goo.gl/aAvLmU

2. Check JH, Nowroozi K, Choe J, Lurie D, Dietterich C. The effect of endometrial thickness and echo pattern on in vitro fertilization outcome in donor oocyte-embryo transfer cycle. Fertil Steril. 1993; 59; 72-75. Ref.: https://goo.gl/R9S3Ee

3. Dickey RP, Olar TT, Curole DN, Taylor SN, Rye PH. Endometrial pattern and thickness associated with pregnancy outcome after assisted reproductive technologies. Hum Reprod. 1992; 7: 418-421. Ref.: https://goo.gl/QPx5S3

4. Noyes N, Liu HC, Sultan K, Schattman G, Rosenwaks Z. Endometrial thickness appears to be a significant factor in embryo implantation in in-vitro fertilization. Hum Reprod. 1995; 10: 919-922. Ref.: https://goo.gl/f4qv5L

5. Rinaldi L, Lisi F, Floccari A, Lisi R, Pepe G, et al. Endometrial thickness as a predictor of pregnancy after in-vitro fertilization but not after intracytoplasmic sperm injection. Hum Reprod. 1996; 11: 1538-1541. Ref.: https://goo.gl/aw9AfU

6. Yuval Y, Lipitz S, Dor J, Achiron R. The relationships between endometrial thickness, and blood flow and pregnancy rates in in-vitro fertilization. Hum Reprod. 1999; 14: 1067-1071. Ref.: https://goo.gl/bPFSRG

7. De Geyter C, Schmitter M, De Geyter M, Nieschlag E, Holzgreve W, et al. Prospective evaluation of the ultrasound appearance of the endometrium in a cohort of 1,186 infertile women. Fertil Steril. 2000 73: 106-113. Ref.: https://goo.gl/ekZcCq

8. Bassil S. Changes in endometrial thickness, width, length and pattern in predicting pregnancy outcome during ovarian stimulation in in vitro fertilization. Ultrasound Obstet Gynecol. 2001; 18: 258-263. Ref.: https://goo.gl/f1dGzH

9. Schild RL, Knobloch C, Dorn C, Fimmers R, van der Ven H, et al. Endometrial receptivity in an in vitro fertilization program as assessed by spiral artery blood flow, endometrial thickness, endometrial volume, and uterine artery blood flow. Fertil Steril. 2001; 75: 361-366. Ref.: https://goo.gl/dnMFV3

10. Zhang $\mathrm{X}$, Chen $\mathrm{CH}$, Confino $\mathrm{E}$, Barnes R, Milad M, et al. Increased endometrial thickness is associated with improved treatment outcome for selected patients undergoing in vitro fertilization-embryo transfer. Fertil Steril. 2005; 83: 336-340. Ref.: https://goo.gl/MR7bSQ

11. Richter KS, Bugge KR, Bromer JG, Levy MJ. Relationship between endometrial thickness and embryo implantation, based on 1,294 cycles of in vitro fertilization with transfer of two blastocyst-stage embryos. Fertil Steril. 2007; 87: 53-59. Ref.: https://goo.gl/cAUXjp

12. McWilliams GD, Frattarelli JL. Changes in measured endometrial thickness predict in vitro fertilization success. Fertil Steril. 2007; 8: 74-81. Ref.: https://goo.gl/mjLRVA

13. Gargett CE. Uterine stem cells: What is the evidence? Hum Reprod. 2007; 13: 87-101. Ref.: https://goo.gl/EXicq4

14. Ono $M$, Maruyama $T$, Yoshimura $Y$. Regeneration and adult stem cells in the human female reproductive tract. Stem Cell Clon. 2008; 1: 23-29. Ref.: https://goo.gl/Tr7tFf

15. Maruyama $T$, Masuda $H$, Ono $M$, Kajitani $T$, Yoshimura $Y$. Human uterine stem/progenitor cells: their possible role in uterine physiology and pathology. Reprod. 2010; 140: 11-22. Ref.: https://goo.gl/rMTjsg 
16. Wolff EF, Wolff AB, Hongling Du, Taylor HS. Demonstration of multipotent stem cells in the adult human endometrium by in vitro chondrogenesis. Reprod Sci. 2007; 14: 524-533. Ref.: https://goo.gl/2H9zjR

17. Cervelló I, Mirantes $C$, Santamaria X, Dolcet $X$, Matias-Guiu X, et al. Stem cells in human endometrium and endometrial carcinoma. Int J Gynecol Pathol. 2011; 30: 317-327. Ref.: https://goo.gl/m5Gtpj

18. Gargett CE, Chan RWS, Scahwab KE. Endometrial stem cells. Curr Opin Obstet Gynecol. 2007; 19: 377-383. Ref.: https://goo.gl/Yq297f

19. Gargett CE, Schwab KE, Zillwood RM, Nguyen HP, Wu D. Isolation and culture of epithelial progenitors and mesenchymal stem cells from human endometrium. Biol Reprod. 2009; 80: 1136-1145. Ref.: https://goo.gl/eV32Ex

20. Gargett CE, Masuda H. Adult stem cells in the endometrium. Mol Hum Reprod. 2010; 16: 818-834. Ref.: https://goo.gl/69Q1Sr

21. Lindvall 0 , Kokaia Z. Stem cells for the treatment of neurological disorders. Nature. 2006; 441: 1094-1096. Ref.: https://goo.gl/iDgpXT

22. Singec I, Jandial R, Crain A, Nikkhah G, Snyder EY. The leading edge of stem cell therapeutics. Annu Rev Med. 2007; 58: 313-328. Ref.: https://goo.gl/VDBKzm

23. Nagori CB, Panchal SY, Patel H. Endometrial regeneration using autologous adult stem cells followed by conception by in vitro fertilization in a patient of severe Asherman's syndrome. J Hum Reprod Sci. 2011; 4: 43-48. Ref.: https://goo.gl/ALX2CX

24. Sudoma I, Kremenska Y, Pylyp L, Goncharova Y, Zadorozhnaja T, et al. The autologous fat stem cells in the treatment of the atrophic endometrium in women with infertility and the use of ART. Zdoroviye zhenshchiny. 2013; 4: 149-156.

25. Ogawa R. The importance of adipose-derived stem cells and vascularized tissue regeneration in the field of tissue transplantation. Curr Stem Cell Res Ther. 2006; 1:13-20. Ref.: https://goo.gl/gijwtn

26. Zuk PA, Zhu M, Mizuno H, Huang J, Futrell JW, et al. Multilineage cells from human adipose tissue: implications for cell-based therapies. Tissue Eng. 2001; 7: 211-228. Ref.: https://goo.gl/66Kr2H

27. Bernacki SH, Wall ME, Loboa EG. Isolation of human mesenchymal stem cells from bone and adipose tissue. Met Cell Biol. 2008; 86: 257- 278. Ref.: https://goo.gl/b9V6va

28. Bourin P, Bunnell BA, Casteilla L, Dominici M, Katz AJ, et al. Stromal cells from the adipose tissuederived stromal vascular fraction and culture expanded adipose tissue-derived stromal/stem cells: a joint statement of the International Federation for Adipose Therapeutics and Science (IFATS) and the International Society for Cellular Therapy (ISCT). Cytotherapy. 2013; 15: 641-648. Ref.: https://goo.gl/2e6ZCe

29. Korbling M, Estrov Z. Adult stem cells for tissue repair-a new therapeutic concept? N Engl J Med. 2003; 349: 570-582. Ref.: https://goo.gl/c5SV3x

30. Du H, Taylor HS. Stem cells and reproduction. Curr Opin Obstet Gynecol. 2010; 22: 235-241. Ref.: https://goo.gl/C26k1B

31. Salem HK, Thiemermann C. Mesenchymal stromal cells: current understanding and clinical status. Stem Cell. 2010; 28: 585-596. Ref.: https://goo.gl/XqemaE

32. Sudoma I, Kremenska Y, Zukin V, Goncharova Y. Novel treatment for patients with thin endometrium? MSRM International meeting -Implantation - Recurrent Miscarriages Science and Clinical Aspects, Crete, Greece, 2010; 24-26, 22-23.

33. Sudoma I, Pylyp L, Goncharova Y, Zukin V. Endometrial regeneration with autologous adipose derived stem cells resulting in pregnancy with donated oocyte embryos. Hum Reprod. 2012; 27: 342-344. Ref.: https://goo.gl/QXMXDj

34. Check JH, Cohen R. Live fetus following embryo transfer in a woman with diminished egg reserve whose maximal endometrial thickness was less than 4 mm. Clin Exp Obstet Gynecol. 2011; 38: 330-332. Ref.: https://goo.gl/y4op2p

35. Dix E, Check JH. Successful pregnancies following embryo transfer despite very thin late proliferative endometrium. Fertil Steril. 2008; 89: 15-16. Ref.: https://goo.gl/Bygnf5

36. Sundström P. Establishment of a successful pregnancy following in-vitro fertilization with an endometrial thickness of no more than $4 \mathrm{~mm}$. Hum. Reprod. 1998; 13: 1550-1552. Ref.: https://goo.gl/og9hnQ 